\title{
Testicular Cancer Pathologic TNM Finding v7
}

National Cancer Institute

\section{Source}

National Cancer Institute. Testicular Cancer Pathologic TNM Finding v7. NCI Thesaurus. Code C89237.

A pathologic finding about one or more characteristics of testicular cancer, following the rules of the TNM AJCC V7 classification system. Histologic examination of the orchiectomy specimen must be used for the pathologic examination. (from AJCC 7th Ed.) 